medRxiv preprint doi: https://doi.org/10.1101/2020.04.29.20083972; this version posted May 2, 2020. The copyright holder for this preprint (which was not certified by peer review) is the author/funder, who has granted medRxiv a license to display the preprint in perpetuity. It is made available under a CC-BY-NC 4.0 International license.

\title{
Effect of magnesium supplementation on circulating biomarkers of cardiovascular disease
}

Alvaro Alonso, ${ }^{1}$ Lin Y. Chen, ${ }^{2}$ Kyle D. Rudser, ${ }^{3}$ Faye L. Norby, ${ }^{4}$ Mary R. Rooney, ${ }^{5}$ Pamela L. Lutsey ${ }^{4}$

1. Department of Epidemiology, Rollins School of Public Health, Emory University, Atlanta, GA, USA

2. Cardiovascular Division, Department of Medicine, University of Minnesota, Minneapolis, MN, USA

3. Division of Biostatistics, School of Public Health, University of Minnesota, Minneapolis, MN, USA

4. Division of Epidemiology and Community Health, School of Public Health, University of Minnesota, Minneapolis, MN, USA

5. Department of Epidemiology, Johns Hopkins Bloomberg School of Public Health, Baltimore, MD, USA

Corresponding author: Alvaro Alonso, MD, PhD. Department of Epidemiology, Rollins School of Public Health, Emory University, 1518 Clifton Rd NE, CNR 3051, Atlanta, GA 30307. Email:

alvaro.alonso@emory.edu. Phone: +1 4047278714. 
medRxiv preprint doi: https://doi.org/10.1101/2020.04.29.20083972; this version posted May 2, 2020. The copyright holder for this preprint (which was not certified by peer review) is the author/funder, who has granted medRxiv a license to display the preprint in perpetuity. It is made available under a CC-BY-NC 4.0 International license .

\begin{abstract}
Background: Magnesium supplementation may be effective for the prevention of cardiometabolic diseases, but mechanisms are unclear. Proteomic approaches can assist in identifying underlying mechanisms.
\end{abstract}

Methods: We collected repeated blood samples in 52 individuals enrolled in a double-blind trial which randomized participants 1:1 to oral magnesium supplementation (400 mg magnesium / day in the form of magnesium oxide) or matching placebo for 10 weeks. Plasma levels of 91 proteins were measured in baseline and follow-up samples using the Olink Cardiovascular Disease III proximity extension assay panel, and modeled as arbitrary units in $\log _{2}$ scale. We evaluated the effect of oral magnesium supplementation on changes in protein levels and the baseline association between serum magnesium and protein levels. The Holm procedure was used to adjust for multiple comparisons.

Results: Participants were $73 \%$ women, $94 \%$ white, and had a mean age of 62 . Changes in proteins did not significantly differ between the two intervention groups after correction for multiple comparisons. The most statistically significant effects were on myoglobin [difference $-0.319 \log _{2}$ units, $95 \%$ confidence interval $(\mathrm{Cl})(-0.550,-0.088), \mathrm{p}=0.008]$, tartrate-resistant acid phosphatase type $5[-0.187,(-0.328,-$ $0.045), p=0.011]$, tumor necrosis factor ligand superfamily member $13 B[-0.181,(-0.332,-0.031), p=$ $0.019]$, ST2 protein $[-0.198,(-0.363,-0.032), p=0.020]$, and interleukin-1 receptor type $1[-0.144,(-$ $0.273,-0.015), p=0.029]$. Similarly, none of the associations of baseline serum magnesium with protein levels were significant after correction for multiple comparisons.

Conclusion: Though we did not identify statistically significant effects of oral magnesium supplementation in this relatively small study, this study demonstrates the value of proteomic approaches for the investigation of mechanisms underlying the beneficial effects of magnesium supplementation.

Clinical Trials Registration: ClinicalTrials.gov NCT02837328

Keywords: magnesium, proteomics, randomized trial 
medRxiv preprint doi: https://doi.org/10.1101/2020.04.29.20083972; this version posted May 2, 2020. The copyright holder for this preprint (which was not certified by peer review) is the author/funder, who has granted medRxiv a license to display the preprint in perpetuity. It is made available under a CC-BY-NC 4.0 International license .

\section{INTRODUCTION}

Mounting evidence suggests that moderately elevated concentrations of circulating magnesium may reduce the risk of coronary heart disease and atrial fibrillation. This evidence comes from prospective observational studies, ${ }^{1,2}$ Mendelian randomization studies, ${ }^{3,4}$ and studies of magnesium supplementation in secondary prevention. ${ }^{5}$ Mechanisms underlying this potential protective effect are unclear, but may include antiarrhythmic effects, improved glucose homeostasis, better vascular tone and endothelial function, and reduced oxidative stress and inflammation. ${ }^{1,6,7}$

Recent advances in the field of proteomics allow the efficient evaluation of multiple proteins in biological tissues, providing an opportunity to assess simultaneously multiple markers of distinct mechanistic pathways. ${ }^{8}$ This approach has been rarely applied to the study of the effects of oral magnesium supplementation. ${ }^{9}$

To provide novel insights into the pathways linking magnesium and cardiovascular risk, we evaluated the effect of oral magnesium supplementation on multiple cardiovascular-related circulating proteins measured using a novel proteomic assay. This analysis was done using repeated blood samples collected in 52 participants in a double-blind randomized trial testing efficacy and tolerability of $400 \mathrm{mg} /$ day of magnesium oxide compared to placebo for the prevention of supraventricular arrhythmias.

\section{METHODS}

\section{Study population}

Between March and June 2017, we recruited and randomized 59 men and women to receive 400 $\mathrm{mg} /$ daily of oral magnesium, in the form of magnesium oxide, or matching placebo for 12 weeks to determine the effect of oral magnesium supplementation on supraventricular arrhythmias (ClinicalTrials.gov \#NCT02837328). Details about recruitment, inclusion and exclusion criteria, and study procedures have been published elsewhere. ${ }^{10}$ Briefly, we included men and women 55 years of age or older, without a prior history of cardiovascular disease, not using magnesium supplements, and living in the Minneapolis/St. Paul, MN area. Eligible participants attended a baseline visit where they underwent a basic physical exam, blood collection, and had a heart rhythm monitor applied (Zio ${ }^{\circledR}$ XT, iRhythm Technologies, Inc., San Francisco, CA). After wearing the monitor for two weeks, participants were randomized $1: 1$ to $400 \mathrm{mg} /$ daily of magnesium or matching placebo, and the study intervention was mailed. Twelve weeks after the baseline exam (10 weeks after starting study intervention), participants underwent a follow-up visit, which included blood collection. For this analysis, we included 52 trial participants with blood samples available for proteomic analysis at baseline (pre-randomization) and the follow-up visit. The University of Minnesota Institutional Review Board approved the study protocol, and all participants provided written informed consent.

\section{Intervention}

The University of Minnesota Institute for Therapeutics Discovery and Drug Development manufactured the study intervention ( $400 \mathrm{mg}$ of magnesium, in the form of magnesium oxide capsules) and the placebo (lactose) following Good Manufacturing Practices. The University of Minnesota Investigational Drug Service managed bottling. Participants and study staff were blinded to the treatment given.

\section{Blood biomarker analysis}


medRxiv preprint doi: https://doi.org/10.1101/2020.04.29.20083972; this version posted May 2, 2020. The copyright holder for this preprint (which was not certified by peer review) is the author/funder, who has granted medRxiv a license to display the preprint in perpetuity. It is made available under a CC-BY-NC 4.0 International license .

Participants were asked to fast for eight hours prior to blood draws at the baseline and follow-up visits. Serum and plasma samples were obtained and processed using standard procedures, and stored in $80^{\circ} \mathrm{C}$ freezers. Circulating magnesium was measured in serum samples using the Roche Cobas 6000 at the University of Minnesota Advanced Research and Diagnostic Laboratory.

\section{Proteomic measurements}

Relative levels of 92 proteins were measured in never-thawed plasma samples using the Olink Cardiovascular III panel (www.olink.com, Olink Proteomics, Uppsala, Sweden). The Olink panel uses a proximity extension assay (PEA) to measure multiple protein biomarkers simultaneously. ${ }^{11}$ Briefly, for each protein, a unique pair of oligonucleotide-labeled antibody probes bind to the targeted protein, and if the two probes are brought in close proximity, the oligonucleotides will hybridize in a pairwise manner. The addition of a DNA polymerase leads to a proximity-dependent DNA polymerization event, generating a unique polymerase chain reaction target sequence. The resulting DNA sequence is subsequently detected and quantified using a microfluidic real-time polymerase chain reaction instrument (Biomark HD, Fluidigm, South San Francisco, CA). Data are then quality controlled and normalized using an internal extension control and an interplate control, to adjust for intra- and interrun variation. The protein levels are given in Normalized Protein eXpression (NPX) units, which is an arbitrary measure on the $\log _{2}$-scale, with higher values corresponding to higher protein concentrations. All assay characteristics including detection limits and measurements of assay performance and validations are available from the manufacturer's webpage (http://www.olink.com). The analyses were based on $1 \mu \mathrm{L}$ of plasma for each panel of 92 assays. To avoid batch effects, samples from the two intervention groups and the two visits were randomized across assay plates. Each plate included internal controls, as described previously, to adjust for technical variation and sample irregularities. ${ }^{11}$ Due to technical issues, one of the protein assays [C-C motif chemokine 22] was not performed, resulting in measurements of 91 proteins.

\section{Other covariates}

At the baseline and follow-up clinic visits, participants self-reported their age, sex, race, and smoking status. Trained technicians measured height, weight and blood pressure, and performed a phlebotomy. Anthropometric measures were obtained with the participant wearing light clothing and no shoes. Blood pressure was measured three times with the participant sitting after a five minute rest.

\section{Statistical analysis}

The primary goal of the analysis was to evaluate the effect of magnesium supplementation versus placebo on change in levels of multiple cardiovascular-related circulating proteins. Of the 91 measured proteins in the array, we excluded those with $>25 \%$ values below the limit of detection across both groups combined as well as those with excessive within-person variability, for which an intervention effect would be unlikely to be detected. One protein [spondin-1 (SPON1)] was excluded due to large number of values below the limit of detection. To evaluate within-person variability, we determined pairwise correlations between measurements from samples collected at the baseline and follow-up visits in the placebo group, and excluded proteins with $r<0.3$. Three proteins were identified as having excessive variability, and subsequently excluded: ephrin type-B receptor 4 (EPHB4), azurocidin (AZU1), and kallikrein-6 (KLK6). Supplementary Table S1 presents complete results for the pairwise correlations 
medRxiv preprint doi: https://doi.org/10.1101/2020.04.29.20083972; this version posted May 2, 2020. The copyright holder for this preprint (which was not certified by peer review) is the author/funder, who has granted medRxiv a license to display the preprint in perpetuity. It is made available under a CC-BY-NC 4.0 International license .

and the proportion of samples with values below the limit of detection. In all, 87 proteins were available for analysis.

We used multiple linear regression with robust variance estimation to evaluate the effect of oral magnesium supplementation on change in levels of individual proteins (modeled as $\log _{2}$-transformed units). The dependent variable was difference in protein levels (follow-up visit minus baseline visit). Models adjusted for randomization stratification factor (age $<65$ vs. $\geq 65$ ) and baseline value of the protein. Since this was an exploratory hypothesis-free analysis, multiple comparisons were taken into account using the Holm procedure. ${ }^{12}$ A secondary analysis was performed adjusting for sex. In an additional analysis, we assessed the baseline cross-sectional associations of serum magnesium with individual proteins, considering baseline levels of the protein as the dependent variable and serum magnesium, modeled as a continuous variable, as the main independent variable, adjusting for age (continuous), sex, and race. The analyses were conducted using SAS version 9.4 (SAS Inc., Cary, NC, USA).

The sample size of the original trial $(n=60)$ was determined to detect a difference in the change of ectopic supraventricular beats (primary endpoint) between treatment groups of 0.79 standard deviation units with $80 \%$ power and 5\% type I two-sided error and assuming that five participants would not complete the follow-up.

\section{RESULTS}

Of 59 participants in the trial, 52 provided samples at baseline and follow-up visit and had available proteomic data. Of these, 24 were assigned to the magnesium intervention and 28 to the placebo group (Figure 1). Mean age in the two groups was similar (62 years), but the proportion of women was higher in the magnesium intervention group: $88 \%$ versus $61 \%$ in the placebo group (Table 1 ). Change in magnesium concentration was significantly higher for those assigned to magnesium supplementation compared to placebo $(0.09 \mathrm{mg} / \mathrm{dL}, 95 \%$ confidence interval $0.03,0.14, p=0.003)$. This magnitude of change is equivalent to 0.6 standard deviations of baseline magnesium concentration.

An analysis of pairwise correlations between baseline protein levels showed most proteins were not strongly correlated to each other, with three clusters including a total of eleven proteins correlated with $r>0.8$ (Figure 2). A first cluster included P-selectin (SELP), bleomycin (BLM) hydrolase, junctional adhesion molecule A (JAMA), caspase-3 (CASP3), platelet-derived growth factor (PDGF) subunit A, and platelet endothelial cell adhesion molecule (PECAM1). A second cluster included tumor necrosis factor receptor 1 (TNFR1), tumor necrosis factor receptor 2 (TNFR2), and interleukin-18-binding protein (IL18BP). Finally, a third cluster included carboxypeptidase A1 (CPA1) and carboxypeptidase B (CPB1).

The effect of oral magnesium supplementation versus placebo on 87 circulating proteins is reported in Figure 3 and Supplementary Table S2. None of the associations were statistically significant after accounting for multiple comparisons with Holm procedure. The strongest effect was on levels of myoglobin, with a difference of -0.319 NPX units ( $95 \%$ confidence interval $-0.550,-0.088 ; p=0.008$ ) in the change over time between the intervention and placebo groups. Table $\mathbf{2}$ and Supplementary Figure S1 present results for the five proteins with between-group differences with $p$-value $<0.05$. Associations were of similar magnitude after adjustment for sex (Supplementary Table S3). 
medRxiv preprint doi: https://doi.org/10.1101/2020.04.29.20083972; this version posted May 2, 2020. The copyright holder for this preprint (which was not certified by peer review) is the author/funder, who has granted medRxiv a license to display the preprint in perpetuity. It is made available under a CC-BY-NC 4.0 International license .

Evaluating the association of serum magnesium with circulating protein levels, we did not identify any statistically significant associations using the Holm procedure to account for multiple comparisons (Figure 4 and Supplementary Table S4). Four proteins had associations with a p-value $<0.05$ (Table 3). The strongest was the association between serum magnesium and epidermal growth factor receptor (beta $=0.053 \mathrm{NPX}$ units, $95 \% \mathrm{Cl} 0.013,0.093, \mathrm{p}=0.011$, per $0.1 \mathrm{mg} / \mathrm{dL}$ difference in serum magnesium).

\section{DISCUSSION}

In this analysis, we evaluated the effect of oral magnesium supplementation on the circulating levels of multiple proteins related to cardiovascular disease. We observed that, compared to placebo, oral magnesium supplementation led to changes in levels of several proteins. For those with $p$-values $<0.05$, all associations were in the hypothesized direction, with $\mathrm{Mg}$ supplementation versus placebo associated with more advantageous levels of cardiovascular proteins. Similarly, we observed associations between baseline serum magnesium and several circulating proteins. However, none of the associations explored were statistically significant after correcting for multiple comparisons.

Growing observational evidence indicates that lower levels of circulating magnesium are associated with increased risk of atrial fibrillation and coronary heart disease. ${ }^{1,2}$ Also, experimental studies show that magnesium supplementation can be effective in the secondary prevention of cardiac arrhythmias. ${ }^{5,13}$ Mechanisms underlying these associations, however, are unknown. Though we failed to identify significant effects of magnesium on circulating proteins, the magnitude of the protein changes after a relatively short intervention supports the use of proteomic panels in future larger studies of magnesium supplementation. These panels will facilitate the identification of biomarkers and physiological pathways responsible for the potential effects of magnesium on cardiovascular risk.

To date, the use of proteomic approaches to evaluate effects of magnesium supplementation has been extremely limited. In a crossover trial of 14 healthy overweight individuals, supplementation with 500 $\mathrm{mg} /$ day of magnesium (in the form of magnesium citrate) vs placebo for 4 weeks did not result in consistent changes in circulating inflammatory biomarkers. However, urine proteomic profiling identified significant differences in the expression profiles of the proteome (but not specific proteins). ${ }^{9}$ Similarly, a study of 52 overweight and obese individuals randomized to $350 \mathrm{mg} /$ day of magnesium or placebo for 24 weeks evaluated the effect of the intervention on multiple circulating biomarkers of inflammation and endothelial dysfunction. No significant differences were reported between the two intervention groups. ${ }^{14}$

The proteins for which we observed some evidence of effect (albeit not significant after multiple correction) are involved in muscle structure and oxygen storage (myoglobin), ${ }^{15}$ immune function and inflammation (tumor necrosis factor ligand superfamily member $13 \mathrm{~B},{ }^{16} \mathrm{ST} 2$ protein, ${ }^{17}$ interleukin-1 receptor type 1), ${ }^{18}$ and bone metabolism (tartrate-resistant acid phosphatase type 5). ${ }^{19}$ Of interest, higher circulating levels of ST2 have been linked to adverse cardiovascular outcomes. ${ }^{20}$ Similarly, in our cross-sectional analysis, higher concentrations of serum magnesium were associated with higher levels of proteins involved in multiple functions (epidermal growth factor receptor), ${ }^{21}$ cell adhesion (junctional adhesion molecule $\mathrm{A}^{22}$ platelet endothelial cell adhesion molecule), ${ }^{23}$ and oxidative stress protection (paraoxonase 3 ). ${ }^{24}$ These effects are consistent with some of the proposed effects of magnesium supplementation, including reductions in oxidative stress and inflammation. 6,7 
medRxiv preprint doi: https://doi.org/10.1101/2020.04.29.20083972; this version posted May 2, 2020. The copyright holder for this preprint (which was not certified by peer review) is the author/funder, who has granted medRxiv a license to display the preprint in perpetuity. It is made available under a CC-BY-NC 4.0 International license .

Our study has some strengths, including the randomized design, the demonstrated efficacy of the intervention in increasing circulating magnesium, ${ }^{10,25}$ and the simultaneous assessment of multiple circulating proteins. However, this analysis is hindered by the limited sample size and absence of replication in an independent sample. Also, we lacked information on kidney function, which influences levels of numerous proteins. However, by including a healthy sample, this is less likely to be an issue.

In summary, our study demonstrated the potential value of proteomic approaches for the investigation of mechanisms underlying the beneficial effects of magnesium supplementation. Future trials in larger samples are needed to establish with certainty the physiological impact of magnesium and, therefore, inform the development of magnesium-based interventions for the prevention of cardiovascular and metabolic diseases.

\section{FUNDING}

This work was supported by internal funds of the Division of Epidemiology and Community Health, University of Minnesota, the McKnight Land-Grant Professorship funds, the American Heart Association grant 16EIA26410001 (Alonso), the National Heart, Lung, And Blood Institute grants T32HL007779 and T32HL007024 (Rooney), the National Center for Advancing Translational Sciences award UL1TR002494. Dr. Alonso was additionally supported by the National Heart, Lung, And Blood Institute of the National Institutes of Health under award number K24HL148521. The content is solely the responsibility of the authors and does not necessarily represent the official views of the National Institutes of Health.

\section{ACKNOWLEDGEMENTS}

We thank the study participants, for taking part in this study.

\section{CONFLICTS OF INTEREST}

The authors declare no conflicts of interest. 
medRxiv preprint doi: https://doi.org/10.1101/2020.04.29.20083972; this version posted May 2, 2020. The copyright holder for this preprint (which was not certified by peer review) is the author/funder, who has granted medRxiv a license to display the preprint in perpetuity. It is made available under a CC-BY-NC 4.0 International license .

\section{REFERENCES}

1. Del Gobbo LC, Imamura F, Wu JH, De Oliveira Otto MC, Chiuve SE, Mozaffarian D. Circulating and dietary magnesium and risk of cardiovascular disease: a systematic review and meta-analysis of prospective studies. Am J Clin Nutr. 2013;98:160-173.

2. Misialek JR, Lopez FL, Lutsey PL, Huxley RR, Peacock JM, Chen LY, Soliman EZ, Agarwal SK, Alonso A. Serum and dietary magnesium and incidence of atrial fibrillation in whites and in African Americans--Atherosclerosis Risk in Communities (ARIC) Study. Circ J. 2013;77:323-329.

3. Larsson SC, Burgess S, Michaëlsson K. Serum magnesium levels and risk of coronary artery disease: Medelian randomisation study. BMC Medicine. 2018;16:68.

4. Larsson SC, Drca N, Michaëlsson K. Serum magnesium and calcium levels and risk of atrial fibrillation. Circ Genom Precis Med. 2019;12:e002349.

5. Arsenault KA, Yusuf AM, Crystal E, Healey JS, Morillo CA, Nair GM, Whitlock RP. Interventions for preventing post-operative atrial fibrillation in patients undergoing heart surgery. Cochrane Database Syst Rev. 2013:CD003611.

6. Nielsen FH. Magnesium deficiency and increased inflammation: current perspectives. J Inflamm Res. 2018;11:25-34.

7. Morais JB, Severo JS, Santos LR, de Sousa Melo SR, de Oliveira Santos R, de Oliveira AR, Cruz KJ, do Nascimento Marreiro D. Role of magnesium in oxidative stress in individuals with obesity. Biol Trace Elem Res. 2017;176:20-26.

8. Lindsey ML, Mayr M, Gomes AV, Delles C, Arrell DK, Murphy AM, Lange RA, Costello CE, Jin YF, Laskowitz DT, Sam F, Terzic A, Van Eyk J, Srinivas PR, American Heart Association Council on Functional Genomics and Translational Biology, Council on Cardiovascular Disease in the Young, Council on Clinical Cardiology, Council on Cardiovascular and Stroke Nursing, Council on Hypertension, Stroke Council. Transformative impact of proteomics on cardiovascular health and disease: a scientific statement from the American Heart Association. Circulation. 2015;132:852-872.

9. Chacko SA, Sul J, Song Y, Li X, LeBlanc J, You Y, Butch A, Liu S. Magnesium supplementation, metabolic and inflammatory markers, and global genomic and proteomic profiling: a randomized, double-blind, controlled, crossover trial in overweight individuals. Am J Clin Nutr. 2011;93:463-473.

10. Lutsey PL, Chen LY, Eaton A, Jaeb M, Rudser KD, Neaton JD, Alonso A. A pilot randomized trial of oral magnesium supplementation on supraventricular arrhythmias. Nutrients. 2018;10:E884.

11. Assarsson E, Lundberg M, Holmquist G, Björkesten J, Bucht Thorsen S, Ekman D, Eriksson A, Rennel Dickens E, Ohlsson S, Edfeldt G, Andersson A-C, Lindstedt P, Stenvang J, Gullberg M, Fredriksson S. Homogenous 96-plex PEA immunoassay exhibiting high sensitivity, specificity, and excellent scalability. PLoS One. 2014;9:e95192.

12. Holm S. A simple sequentially rejective multiple test procedure. Scand J Statist. 1979;6:65-70.

13. Salaminia S, Sayehmiri F, Angha P, Sayehmiri K, Motedayen M. Evaluating the effect of magnesium supplementation and cardiac arrhythmias after acture coronary syndrome: a systematic review and meta-analysis. BMC Cardiovasc Disord. 2018;18:129.

14. Joris PJ, Plat J, Bakker SJ, Mensink RP. Effects of long-term magnesium supplementation on endothelial function and cardiometabolic risk markers: A randomized controlled trial in overweight/obese adults. Sci Rep. 2017;7:106.

15. Ordway GA, Garry DJ. Myoglobin: an essential hemoprotein in striated muscle. J Exp Biol. 2004;207:3441-3446.

16. Schneider P, MacKay F, Steiner V, Hofmann K, Bodmer JL, Holler N, Ambrose C, Lawton P, Bixler $\mathrm{S}$, Acha-Orbea H, Valmori D, Romero P, Werner-Favre C, Zubler RH, Browning JL, Tschopp J. 
medRxiv preprint doi: https://doi.org/10.1101/2020.04.29.20083972; this version posted May 2, 2020. The copyright holder for this preprint (which was not certified by peer review) is the author/funder, who has granted medRxiv a license to display the preprint in perpetuity. It is made available under a CC-BY-NC 4.0 International license .

BAFF, a novel ligand of the tumor necrosis family, stimulates B cell growth. $J$ Exp Med. 1999;189:1747-1756.

17. Schmitz J, Owyang A, Oldham E, Song Y, Murphy E, McClanahan TK, Zurawski G, Moshrefi M, Qin J, Li X, Gorman DM, Bazan JF, Kastelein RA. IL-33, an interleukin-1-like cytokine that signals via the IL-1 receptor-related protein ST2 and induces T helper type 2-associated cytokines. Immunity. 2005;23:479-490.

18. Tominaga K, Yoshimoto T, Torigoe K, Kurimoto M, Matsui K, Hada T, Okamura H, Nakanishi K. IL12 synergizes with IL-18 or IL-1beta for IFN-gamma production from human T cells. Int Immunol. 2000;12:151-160.

19. Halleen JM, Ylipahkala H, Alatalo SL, Janckila AJ, Heikkinen JE, Suominen H, Cheng S, Väänänen HK. Serum tartrate-resistant acid phosphatase $5 b$, but not $5 a$, correlates with other markers of bone turnover and bone mineral density. Calcif Tissue Int. 2002;71:20-25.

20. Pascual-Figal DA, Januzzi JL. The biology of ST2: the International ST2 Consensus Panel. Am J Cardiol. 2015;115:3B-7B.

21. Seshacharyulu P, Ponnusamy MP, Haridas D, Jain M, Ganti AK, Batra SK. Targeting the EGFR signaling pathway in cancer therapy. Expert Opin Ther Targets. 2012;16:15-31.

22. Steinbacher $T$, Kummer $D$, Ebnet $K$. Junctional adhesion molecule-A: functional diversity through molecular promiscuity. Cell Mol Life Sci. 2018;75:1393-1409.

23. Lertkiatmongkol P, Liao D, Mei H, Hu Y, Newman PJ. Endothelial functions of platelet/endothelial cell adhesion molecule-1 (CD31). Curr Opin Hematol. 2016;23:253-259.

24. Précourt LP, Amre D, Denis MC, Lavoie JC, Delvin E, Seidman E, Levy E. The three-gene paraoxonase family: physiologic roles, actions and regulation. Atherosclerosis. 2011;214.

25. Zhang X, Del Gobbo LC, Hruby A, Rosanoff A, He K, Dai Q, Costello RB, Zhang W, Song Y. The circulating concentration and 24-h urine excretion of magnesium dose- and time-dependently respond to oral magnesium supplementation in a meta-analysis of randomized controlled trials. J Nutr. 2016;146:595-602. 
medRxiv preprint doi: https://doi.org/10.1101/2020.04.29.20083972; this version posted May 2, 2020. The copyright holder for this preprint (which was not certified by peer review) is the author/funder, who has granted medRxiv a license to display the preprint in perpetuity.

It is made available under a CC-BY-NC 4.0 International license.

\section{FIGURE LEGENDS}

Figure 1. Participant flow diagram.

Figure 2. Pairwise correlations between baseline levels of individual proteins

Figure 3. Mean difference in 12-week change of individual protein levels in Normalized Protein eXpression (NPX) units comparing oral magnesium supplementation to placebo. Error bars correspond to $95 \%$ confidence. Green bars indicate differences with $p<0.05$, yellow bars with $p$-value $\geq 0.05$ and $<0.10$.

Figure 4. Baseline association of serum magnesium with individual protein levels in Normalized Protein eXpression (NPX) units. Coefficients correspond to difference in protein levels per $0.1 \mathrm{mg} / \mathrm{dL}$ difference in serum magnesium. Error bars correspond to $95 \%$ confidence intervals. Green bars indicate differences with $p<0.05$, yellow bars with $p$-value $\geq 0.05$ and $<0.10$ 
medRxiv preprint doi: https://doi.org/10.1101/2020.04.29.20083972; this version posted May 2, 2020. The copyright holder for this preprint (which was not certified by peer review) is the author/funder, who has granted medRxiv a license to display the preprint in perpetuity.

It is made available under a CC-BY-NC 4.0 International license .

Table 1. Baseline characteristics of study participants by treatment assignment. Values presented are mean (SD) or frequency (\%) where indicated.

\begin{tabular}{|l|l|l|}
\hline & $\begin{array}{l}\text { Magnesium } \\
\text { (400 mg daily) }\end{array}$ & Placebo \\
\hline $\mathrm{N}$ & 24 & 28 \\
\hline Age, years & $62(5)$ & $62(6)$ \\
\hline Women, $\mathrm{n}(\%)$ & $21(88)$ & $17(61)$ \\
\hline Non-white, $\mathrm{n}(\%)$ & $2(8)$ & $1(4)$ \\
\hline Body mass index, $\mathrm{kg} / \mathrm{m}^{2}$ & $28.3(5.1)$ & $27.8(4.2)$ \\
\hline Systolic blood pressure, $\mathrm{mmHg}$ & $118(15)$ & $119(17)$ \\
\hline Diastolic blood pressure, $\mathrm{mmHg}$ & $73(8)$ & $71(8)$ \\
\hline Serum magnesium, $\mathrm{mg} / \mathrm{dL}$ & $2.1(0.2)$ & $2.1(0.1)$ \\
\hline
\end{tabular}


medRxiv preprint doi: https://doi.org/10.1101/2020.04.29.20083972; this version posted May 2, 2020. The copyright holder for this preprint (which was not certified by peer review) is the author/funder, who has granted medRxiv a license to display the preprint in perpetuity. It is made available under a CC-BY-NC 4.0 International license .

Table 2. Effect of magnesium supplementation on selected circulating proteins, expressed as difference in change between magnesium and placebo group, in Normalized Protein eXpression (NPX) units.

Results for effects with $p$-value $<0.05$

\begin{tabular}{|l|l|c|c|c|}
\hline \multicolumn{2}{|l|}{ Protein } & $\begin{array}{c}\text { Difference in } \\
\text { change in protein } \\
\text { (NPX units) }\end{array}$ & 95\%Cl & p-value \\
\hline MB & Myoglobin & -0.319 & $-0.550,-0.088$ & 0.008 \\
\hline TR-AP & Tartrate-resistant acid phosphatase type 5 & -0.187 & $-0.328,-0.045$ & 0.011 \\
\hline TNFSF13B & $\begin{array}{l}\text { Tumor necrosis factor ligand superfamily } \\
\text { member 13B }\end{array}$ & -0.181 & $-0.332,-0.031$ & 0.019 \\
\hline ST2 & ST2 protein & -0.198 & $-0.363,-0.032$ & 0.020 \\
\hline IL-1RT1 & Interleukin-1 receptor type 1 & -0.144 & $-0.273,-0.015$ & 0.029 \\
\hline
\end{tabular}

Results from general linear model with difference in protein values between follow-up and baseline measurements in Normalized Protein eXpression (NPX) units as the dependent variable, treatment assignment as main independent variable, adjusted for baseline levels of the protein and age stratum. 
medRxiv preprint doi: https://doi.org/10.1101/2020.04.29.20083972; this version posted May 2, 2020. The copyright holder for this preprint (which was not certified by peer review) is the author/funder, who has granted medRxiv a license to display the preprint in perpetuity. It is made available under a CC-BY-NC 4.0 International license.

Table 3. Association of baseline serum magnesium with levels of selected circulating proteins. Estimates correspond to difference in protein levels, expressed in Normalized Protein eXpression (NPX) units, per $0.1 \mathrm{mg} / \mathrm{dL}$ difference in serum magnesium. Results for associations with $\mathrm{p}$-value $<0.05$.

\begin{tabular}{|l|l|c|c|c|}
\hline Protein & \multicolumn{1}{|c|}{$\begin{array}{c}\text { Difference in } \\
\text { protein levels } \\
\text { (NPX units) }\end{array}$} & 95\% & \\
\hline EGFR & Epidermal growth factor receptor & 0.053 & $0.013,0.093$ & 0.011 \\
\hline JAM-A & Junctional adhesion molecule A & 0.180 & $0.020,0.339$ & 0.028 \\
\hline PON3 & Paraoxonase 3 & 0.137 & $0.039,0.007$ & 0.039 \\
\hline PECAM-1 & $\begin{array}{l}\text { Platelet endothelial cell adhesion } \\
\text { molecule }\end{array}$ & 0.121 & $0.002,0.241$ & 0.046 \\
\hline
\end{tabular}

Results from general linear model with baseline levels of protein in Normalized Protein eXpression (NPX) units as the dependent variable, serum magnesium as main independent variable, adjusted for age, sex, and race. 


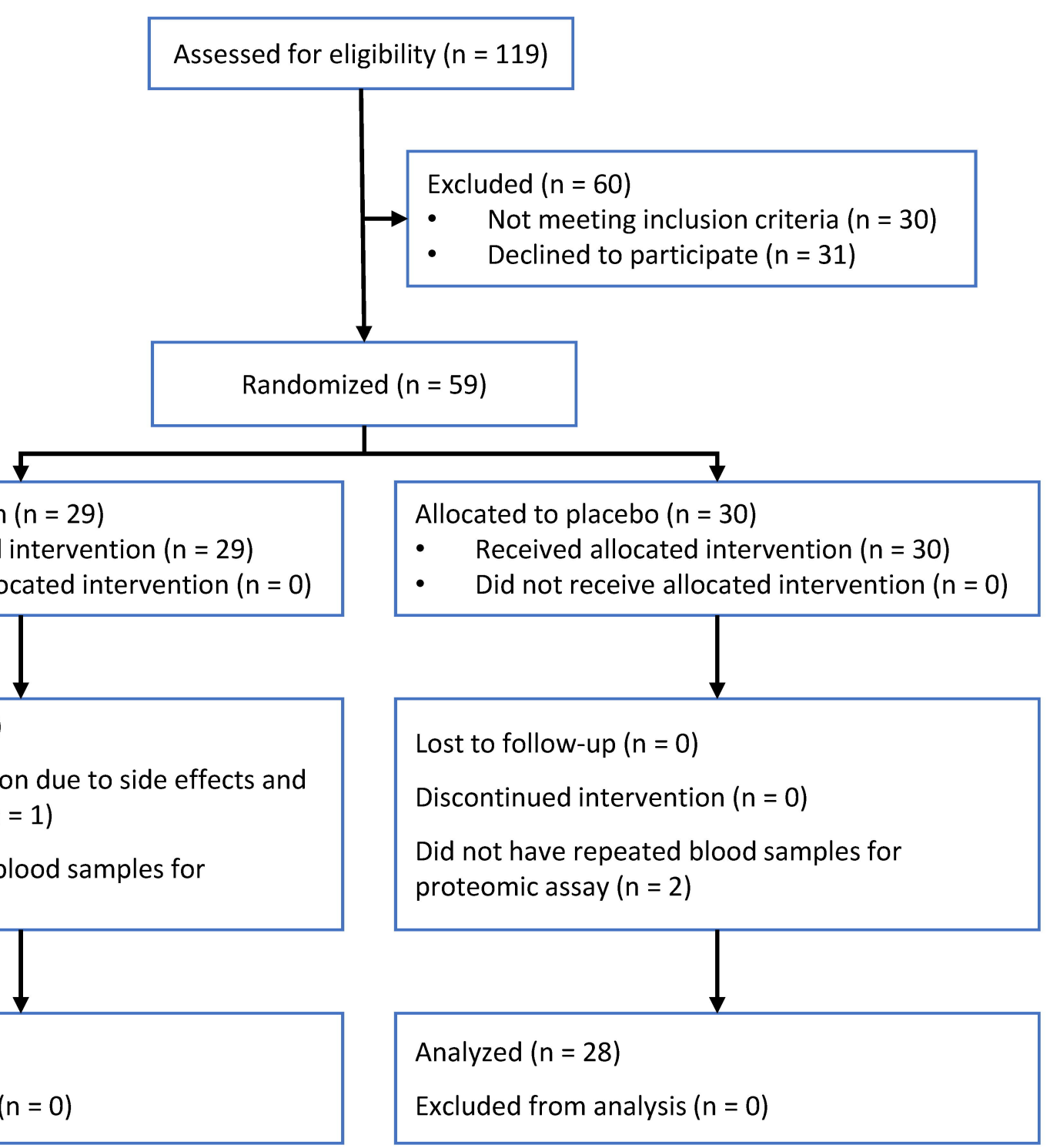

Allocated to magnesium ( $n=29$ )

- $\quad$ Received allocated intervention $(n=29)$

- $\quad$ Did not receive allocated intervention $(n=0)$

Lost to follow-up $(n=0)$

Discontinued intervention due to side effects and dropped out of study $(n=1)$

Did not have repeated blood samples for proteomic assay $(n=5)$

\begin{tabular}{l|} 
Analyzed $(n=24)$ \\
Excluded from analysis $(n=0)$
\end{tabular}

Excluded

- $\quad$ Not meeting inclusion criteria $(n=30)$

- $\quad$ Declined to participate $(n=31)$

Allocated to placebo $(n=30)$

- $\quad$ Received allocated intervention $(n=30)$

- Did not receive allocated intervention $(n=0)$

$$
\text { Lost to follow-up ( } n=0 \text { ) }
$$

Discontinued intervention $(n=0)$

Did not have repeated blood samples for proteomic assay $(n=2)$
Excluded from analysis $(n=0)$ 


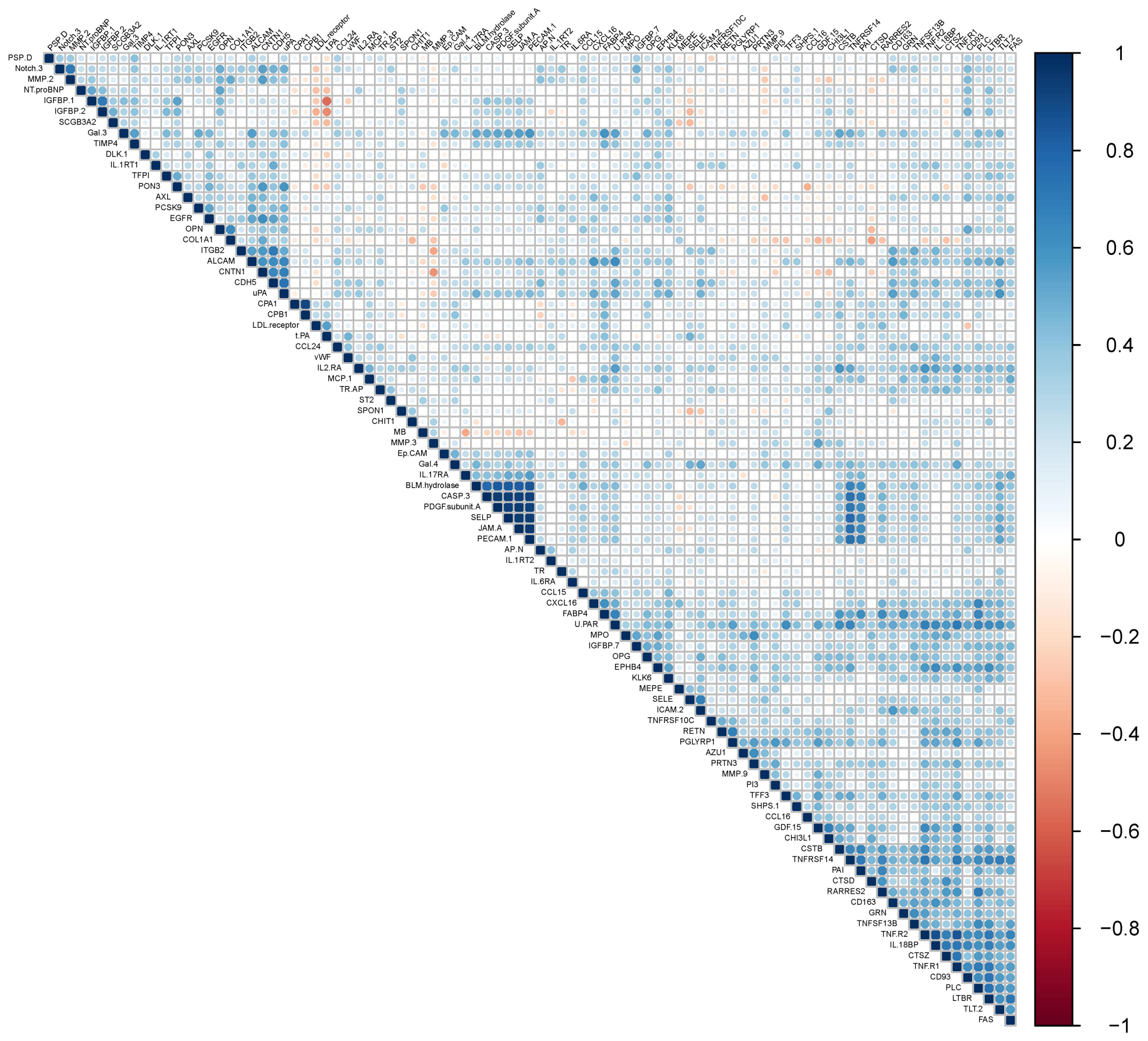


0.8

0.6

0.4

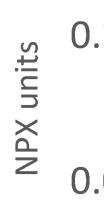

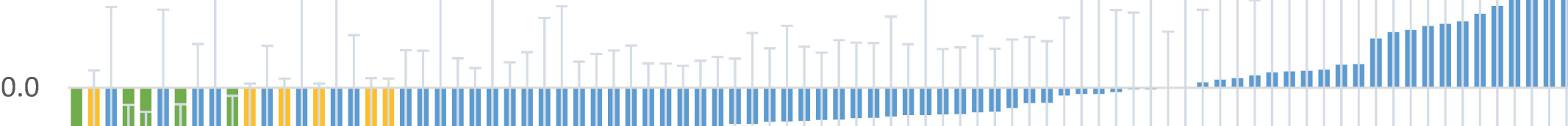

$-0.2$

(1)

$-0.4$

$-0.6$

$-0.8$

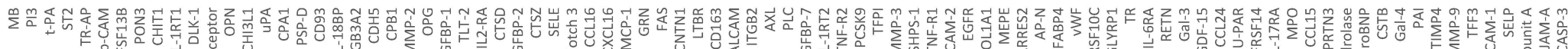
岀崇

(n)

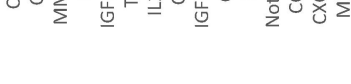

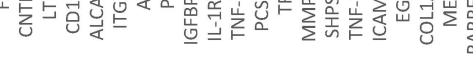


0.4

0.2

(

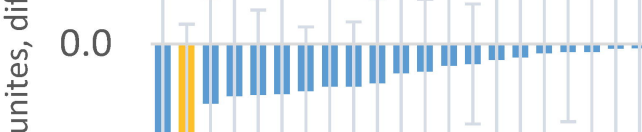

ํ.

$-0.2$

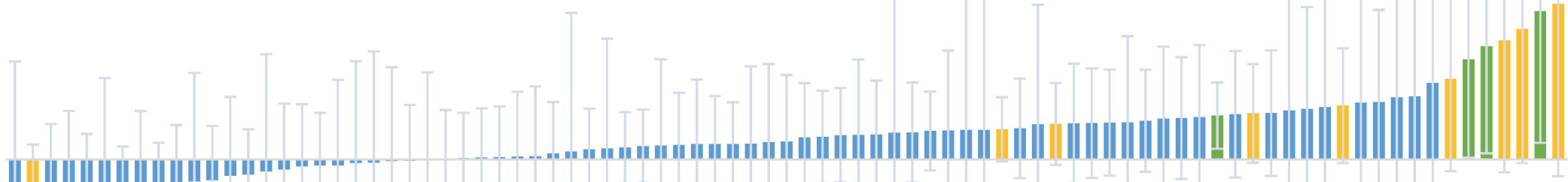

$-0.4$

$-0.6$

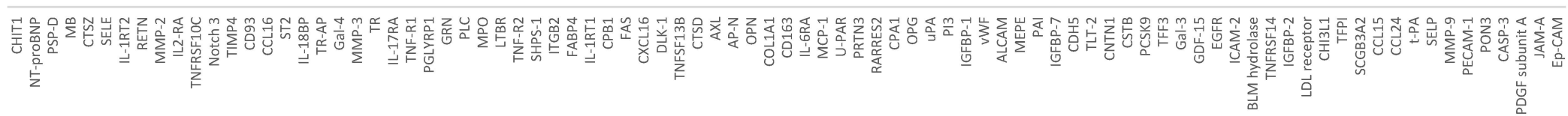

